Tersedia online di: http://ejournal-balitbang.kkp.go.id/index.php/bawal
e-mail:bawal.puslitbangkan@ @mail.com
BAWAL wIDYA RISET PERIKANAN TANGKAP
Volume 9 Nomor 3 Desember 2017
e-ISSN: 2502-6410
BAWAL

\title{
KEBIASAAN MAKANAN DAN INTERAKSI TROFIK KOMUNITAS UDANG PENAEID DI PERAIRAN ACEH TIMUR
}

\section{FOOD HABITS AND TROPHIC INTERACTION OF PENAEID SHRIMPS COMMUNITIES IN THE WATERS OF EAST ACEH}

\author{
Agus Arifin Sentosa*1, Dimas Angga Hedianto ${ }^{1}$, dan Astri Suryandari ${ }^{1}$ \\ ${ }^{1}$ Balai Riset Pemulihan Sumber Daya Ikan, Jalan Cilalawi No. 01 Jatiluhur, Purwakarta, Jawa Barat, -41152, Indonesia \\ Teregistrasi I tanggal: 26 Mei 2017; Diterima setelah perbaikan tanggal: 05 Januari 2018; \\ Disetujui terbit tanggal: 09 Januari 2018
}

\begin{abstract}
ABSTRAK
Udang penaeid merupakan komoditas perikanan udang yang umum tertangkap di perairan Aceh Timur. Pengelolaan perikanan udang dengan pendekatan ekosistem membutuhkan informasi terkait kebiasaan makanan udang dan interaksinya. Penelitian ini bertujuan untuk mengetahui kebiasaan makanan dan interaksi trofik komunitas udang penaeid di perairan Aceh Timur. Penelitian dilaksanakan pada April dan September tahun 2014-2015 serta April 2016 di perairan Aceh Timur. Contoh udang diperoleh dari tangkapan mini beam trawl dan hasil tangkapan nelayan. Analisis dilakukan menggunakan indeks bagian terbesar, tingkat trofik, luas relung dan interaksinya. Hasil penelitian menunjukkan komunitas udang penaeid di perairan pantai Aceh Timur terdapat sekitar 20 jenis udang pada stadia yuwana hingga dewasa. Kebiasaan makanan pada 8 jenis udang penaeid dominan berbeda tergantung spesiesnya dengan makanan utama berupa krustasea, detritus dan moluska. Interaksi trofik menunjukkan terdapat peluang kompetisi yang tinggi antara Penaeus monodon dengan Penaeus sp., Fenneropenaeus indicus, F. merguiensis dan Parapenaeopsis stylifera coromandelica serta Metapenaeus brevicornis dengan $M$. ensis karena memanfaatkan sumberdaya makanan yang sama.
\end{abstract}

Kata Kunci: Udang Penaeid; kebiasaan makanan; intraksi trofik; Aceh Timur

\section{ABSTRACT}

The penaeid shrimps communities have been caught in the waters of East Aceh and some become the main fisheries commodities. Management of shrimp fisheries with ecosystem approach required information related to its food habits and their interactions. The purpose of this study were to examine food habits and trophic interactions of penaeid shrimp communities in the East Aceh waters. The study was conducted in April and September 2014-2015 and April 2016 in the waters of East Aceh. Shrimp samples were obtained from mini beam trawl and fisherman catches. The analysis was performed using index of preponderance, trophic level, niche breadth and its interaction. The results showed that the community of Penaeid shrimp in East Aceh coastal waters consisted of about 20 species of shrimp in juvenile to to adult phase. Food habits of 8 dominant penaeid shrimp was differ depending on the species with the main foods of crustaceans, detritus and molluscs. Trophic interactions suggest that there is a high probability of competition between Penaeus monodon and Penaeus sp., Fenneropenaeus indicus, F. merguiensis and Parapenaeopsis stylifera coromandelica and Metapenaeus brevicornis with $M$. ensis for utilizing the same food resources.

\section{Keywords: Penaeid shrimps; food habits; trophic interaction; East Aceh}

\section{PENDAHULUAN}

Sumber daya udang merupakan salah satu komoditas utama dari sektor perikanan udang atau krustasea di Indonesia, terutama dari famili Penaeidae yang memiliki nilai ekonomis yang tinggi (Erawati, 2000; Pangesti, 2011; Romimohtarto \& Juwana, 2009). Salah satu daerah Korespondensi penulis:

e-mail:agusarifinsentosa7@gmail.com

Telp. +6285228540911 penghasil udang penaeid adalah pesisir Aceh (Hedianto et al., 2016; Wardana, 2011) dengan jenis produksi udang penaeid yang utama adalah udang windu (Penaeus monodon) yang merupakan produk perikanan unggulan dari Provinsi Aceh. Berdasarkan data Direktorat Jenderal Perikanan Tangkap Kementerian Kelautan dan Perikanan (DJPT KKP) Tahun 2016 menunjukkan bahwa estimasi 
produksi udang penaeid terakhir sekitar 4800 ton dengan nilai total sekitar Rp 361 milyar. Kontribusi produksi udang windu sekitar 2400 ton atau $49 \%$ dari total udang penaeid. Lante et al. (2015) dan Riani (2000) melaporkan bahwa kualitas udang windu dari Aceh cukup baik sebagai sumber induk alami yang potensial untuk kegiatan budidaya.

Salah satu daerah penyebaran udang penaeid di Aceh terletak di pantai timur Pidie, Lhokseumawe dan Langsa yang berada di pesisir timur Aceh dan merupakan bagian dari Wilayah Pengelolaan Perikanan (WPP) 571 Selat Malaka (Suman et al., 1992; Sumiono, 2012). Aktivitas penangkapan udang penaeid di pesisir Aceh Timur dilakukan oleh nelayan dengan alat tangkap berupa trammel net (jaring tiga lapis), bottom trawl (langgih dan pukat layang) serta pukat pantai/jaring arad (Kembaren \& Ernawati, 2015; Purwanto, 2015). Alat tangkap tersebut dioperasikan di dasar perairan mengingat karakteristik udang penaeid yang bersifat demersal dan mencari makanan di dasar perairan (Chan, 1998; Dall et al., 1990).

Keberadaan komunitas udang penaeid pada suatu habitat perairan dipengaruhi oleh ketersediaan makanannya (Dall et al., 1990; Purnamaningtyas \& Hedianto, 2015). Pemanfaatan sumber daya makanan alami di habitat yang sama akan berpotensi terjadinya interaksi antar dan interspesies berupa kompetisi (Asriyana, 2011; Wijaya, 2015) sehingga penting untuk mengetahui informasi terkait kebiasaan makanan alami setiap jenis udang penaeid di pesisir Aceh Timur. Informasi tersebut dapat memberikan deskripsi terkait jenis-jenis makanan alaminya sehingga dapat diketahui tingkat trofik, relung ekologi dan interaksinya dalam komunitas (Bakhtiyar et al., 2014; Chaves \& Umbria, 2003; Effendie, 2002; Krebs, 1989; Lima et al., 2014). Asriyana (2011) menyebutkan bahwa interaksi trofik merupakan keterkaitan antar organisme perairan dalam suatu jejaring makanan dimana informasi tersebut bermanfaat bagi pengelolaan perikanan dengan pendekatan ekosistem.

Studi terkait kebiasaan makanan alami beberapa udang penaeid telah banyak dilaporkan di beberapa negara. Abu Hena \& Hishamuddin (2012) melaporkan bahwa berdasarkan observasi di tambak Malaysia menunjukkan makanan Penaeus monodon pada fase post larva (PL) dan juvenil terdiri atas detritus, krustasea dan serangga sedangkan dewasanya memakan detritus, krustasea, moluska, annelida, rotifera, serangga dan fitoplankton. Penelitian kebiasaan makanan P. monodon lainnya menunjukkan di Laut Merah Sudan juvenil udang windu memakan alga sedangkan dewasanya memakan krustasea, annelida, alga dan detritus (El Hag, 1984), di Pantai
Mallipattinam, India bersifat karnivora (Baskar et al., 2013) dan di estuaria Korapuzha udang tersebut memakan krustasea, ikan, moluska, polichaera dan detritus (Thomas, 1972). Udang P. merguiensis di Selat Malaka bersifat detritivor karnivora dengan perubahan jenis makanan sesuai fase umurnya (Chong \& Sasekumar, 1981) dan larva P. merguiensis di Teluk Carpentaria Australia memiliki makanan utama diatom (Preston et al., 1992) dan juvenilnya memakan krustasea, bivalvia, gastropoda dan polichaeta pada malam hari (Wassenberg \& Hill, 1993). Penelitian AlMaslamani et al. (2007) di Doha, Qatar mengkonfirmasi bahwa daerah padang lamun merupakan habitat penting bagi PL dan juvenil $P$. semisulcatus dimana terdapat hubungan antara zonasi berdasarkan kedalaman dengan kebiasaan makanannya yang berupa bentos seperti foraminifera, polichaeta, diatom dan krustasea kecil dasar lainnya. Metapeneopsis stridulans di Mumbay India memakan diatom, foraminifera, polichaeta, moluska, krustasea dan detritus (Kulkarni et al., 1999).

Penelitian kebiasaan makanan udang penaeid di Aceh Timur masih relatif jarang. Informasi yang umum ditemukan terkait studi udang penaeid di Aceh adalah terkait dengan struktur ukuran tangkapan dan dinamika populasi (Hedianto et al., 2016), upaya penangkapan (Suman et al., 1992) dan budidaya udang penaeid (Wardana, 2011). Interaksi trofik akan memengaruhi hubungan keanekaragaman dan stabilitas proses ekosistem melalui proses interaksi spesies (Nybakken, 1992; Odum, 1993). Informasi tersebut dapat menjadi salah satu bahan masukan dalam rekomendasi pengelolaan sumber daya udang dengan pendekatan ekosistem di pesisir Aceh Timur yang berkelanjutan. Pendekatan ekosistem merupakan pendekatan yang mengikutsertakan keseluruhan komponen utama ekosistem dalam suatu upaya pengelolaan perikanan secara berkelanjutan (Widodo \& Suadi, 2006). Penelitian ini bertujuan untuk mengetahui kebiasaan makanan dan interaksi trofik komunitas udang penaeid di perairan pesisir Aceh Timur.

\section{BAHANDANMETODE}

\section{Lokasi, Waktu dan Metode Pengambilan Contoh}

Penelitian ini dilakukan di pesisir Kabupaten Aceh Timur, Provinsi Aceh pada April dan September tahun 2014 dan 2015 serta April 2016. Waktu pengambilan sampel ditentukan dengan pertimbangan musim barat dan timur. Sampel udang penaeid diperoleh dari hasil tangkapan menggunakan mini beam trawl dan hasil tangkapan nelayan di lokasi pendaratan utama di Kuala Geuleumpang (Julok) dan Peudawa (Gambar 1). 

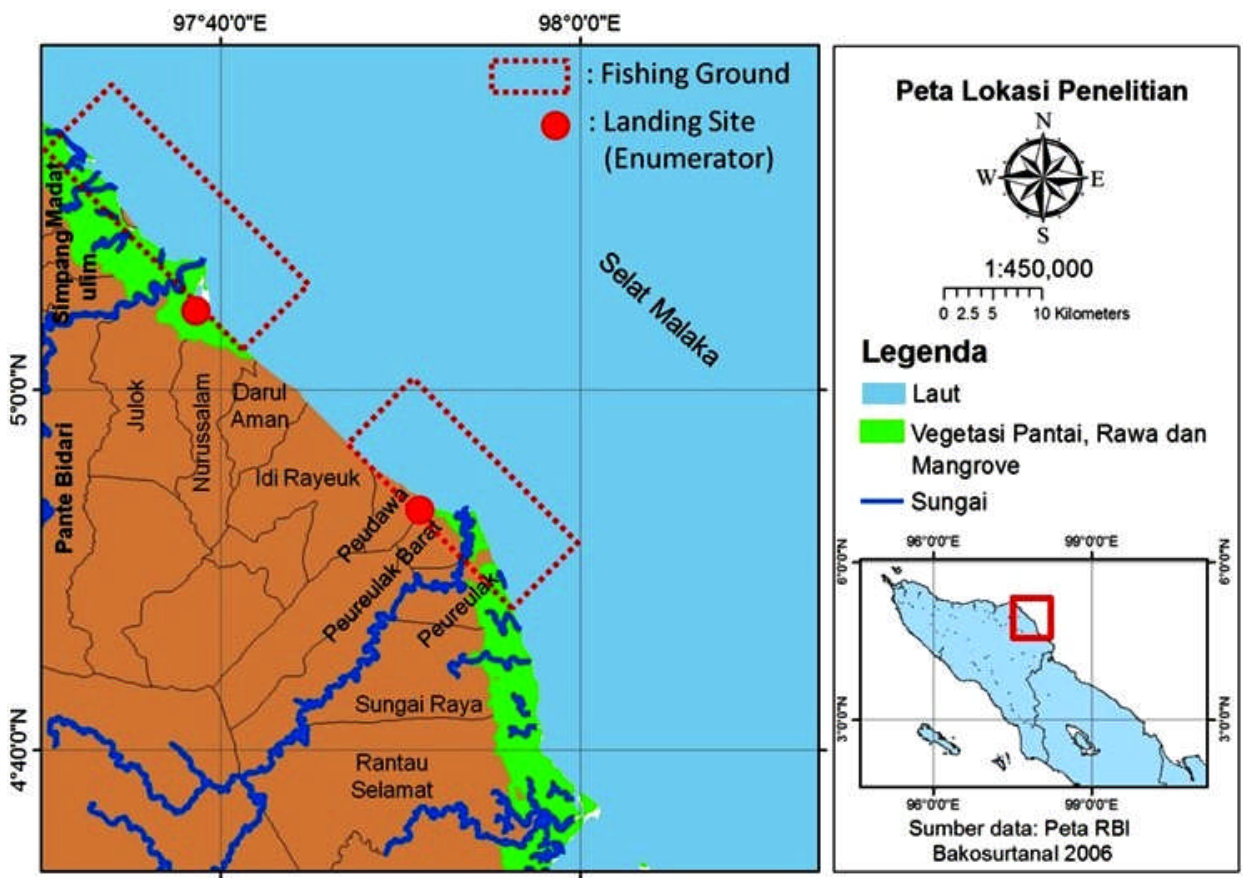

Gambar 1. Peta lokasi penelitian di perairan Aceh Timur.

Figure 1. Site map of research in East Aceh waters.

Udang penaeid yang tertangkap disortir dan diidentifikasi berdasarkan Chan (1998), Holthuis (1980) dan Palomares \& Pauly (2014) kemudian diukur panjang karapasnya menggunakan kaliper dengan ketelitian $1 \mathrm{~mm}$. Pengamatan isi pakan udang diambil dengan pembedahan dari organ pencernaan udang (hepatopankreas) yang terletak di bagian kepala, kemudian diawetkan dengan formalin 5\% dan diamati di Laboratorium Biologi Ikan, Balai Penelitian Pemulihan dan Konservasi Sumber Daya Ikan, Jatiluhur, Purwakarta.

\section{Analisis Data}

Kebiasaan makanan udang dianalisis menggunakan metode indeks bagian terbesar (index of preponderance) (Natarajan \& Jhingran, 1961):

$$
\operatorname{Ii}(\%)=\frac{\mathrm{V}_{\mathrm{i}} \times \mathrm{O}_{\mathrm{i}}}{\sum_{i=1}^{n}\left(V_{i} x O_{i}\right) \times 100}
$$

dimana;

Ii = indeks bagian terbesar (Index of Preponderance) makanan jenis ke-i;

$\mathrm{V}_{\mathrm{i}}=$ persentase volume makanan jenis ke-i;

$\mathrm{O}_{\mathrm{i}} \quad=$ persentase frekuensi kejadian makanan jenis ke$\mathrm{i}$;

$\mathrm{n} \quad=$ jumlah organisme makanan $(\mathrm{i}=1,2,3, \ldots \mathrm{n})$.

Tingkat trofik (troph) udang ditentukan berdasarkan komposisi makanan dan tingkat trofik makanannya (Pauly et al., 2000):

$$
\text { troph }=1+\sum_{j=1}^{G} D C_{i j} \times \text { troph }_{j}
$$

dimana;

troph = tingkat trofik;

$\mathrm{DC}_{\mathrm{ij}}=$ fraksi jenis makanan $\mathrm{j}$ dalam isi lambung individu $\mathrm{i}$;

troph $_{\mathrm{j}}=$ trofik level jenis makanan $\mathrm{j}$;

$\mathrm{G}=$ jumlah kelompok makanan dalam lambung individu $\mathrm{i}$.

Perhitungan luas relung berdasarkan kebiasaan makanan ikan dilakukan dengan menggunakan indek Levin (Collwel \& Futuyma, 1971):

$B j=\left(\sum P_{i}^{2}\right)^{-1}$

dimana:

$\mathrm{Bj}=$ luas relung;

$\mathrm{Pi}=$ proporsi kelompok makanan ke-i yang dikonsumsi.

Analisis pengelompokan (clustering analysis) dilakukan untuk mengetahui interaksi antarjenis udang penaeid berdasarkan kebiasaan makanannya menggunakan analisis multivariat dengan jarak Eucledian dengan bantuan perangkat lunak STATISTICA 8 (Sentosa \& Satria, 2011).

Interaksi trofik komunitas udang dilakukan berdasarkan tumpang tindih relung makanan menggunakan indeks Pianka (Pianka, 1974): 


$$
O_{k j}=\frac{\sum\left(P_{i k} P_{i j}\right)}{\sqrt{\left(\sum P_{i k}^{2} \sum P_{i j}^{2}\right)}}
$$

dimana;

$\mathrm{O}_{\mathrm{kj}}=$ tumpang tindih relung antara spesies $\mathrm{k}$ dan $\mathrm{j}$;

$\mathrm{P}_{\mathrm{ik}} \quad=$ proporsi makanan ke $\mathrm{i}$ pada spesies $\mathrm{k}$;

$\mathrm{P}_{\mathrm{ij}} \quad=$ jumlah makanan ke $\mathrm{i}$ pada spesies $\mathrm{j}$.

Kriteria kriteria tumpang tindih relung $\left(\mathrm{O}_{\mathrm{kj}}\right)$ ditentukan menurut Moyle \& Senanayake (1984) sebagai berikut:

$\mathrm{Okj}<0,3=$ peluang terjadinya kompetisi rendah
$0,3 \mathrm{~d} \leq$ Okj $\mathrm{d} \leq 0,8=$ peluang terjadinya kompetisi sedang Okj $>0,8=$ peluang terjadinya kompetisi tinggi

\section{HASIL DAN BAHASAN Hasil}

Sebanyak 821 ekor dari 20 spesies udang penaeid ditemukan selama penelitian di perairan Aceh Timur (Tabel 1). Komposisi jenis udang penaeid didominasi oleh udang windu (Penaeus monodon). Berdasarkan kisaran ukuran panjang karapasnya, sampel udang penaeid yang diamati telah berada pada fase yuwana hingga dewasa.

Tabel 1. Komposisi udang penaeid yang tertangkap di pesisir Aceh Timur

Table 1. Penaeid shrimps composition caught in coastal East Aceh

\begin{tabular}{llcr}
\hline Spesies/Species & Nama Lokal/Local Name & Kisaran CL \& rerata (cm) & Total \\
\hline Penaeus monodon & Udang Windu & $1,0-7,3(4,24)$ & 343 \\
Fenneropenaeus indicus & Udang Kelong & $1,0-3,4(1,89)$ & 80 \\
Metapenaeus ensis & Udang Swallow & $1,1-2,1(1,44)$ & 69 \\
Metapenaeus dobsoni & Udang Kapur & $0,7-1,8(1,23)$ & 67 \\
Fenneropenaeus merguiensis & Udang Kelong & $1,1-3,6(2,55)$ & 52 \\
Metapenaeus brevicornis & Udang Kapur & $1,1-2,4(1,44)$ & 42 \\
Penaeus sp. & Udang Pisang & $1,2-2,6(1,71)$ & 39 \\
Parapenaeopsis stylifera & Udang Batu & $1,3-1,3(1,30)$ & 31 \\
Parapenaeopsis cornuta & Udang Batu & $1,3-2,2(1,71)$ & 26 \\
Metapenaeus moyebi & Udang Kapur & $1,0-1,8(1,40)$ & 16 \\
Penaeus semisulcatus & Udang Harimau & $1,5-2,3(1,97)$ & 11 \\
Parapenaeopsis hungerfordi & Udang Batu & $1,5-2,6(2,21)$ & 11 \\
Parapenaeopsis sculptilis & Udang Batu & $3,6-3,6(3,60)$ & 8 \\
Melicertus canaliculatus & Udang Harimau & $3,4-3,6(3,60)$ & 8 \\
Metapenaeus lysianassa & Udang Kapur & $1,0-1,4(1,20)$ & 7 \\
Metapenaeus affinis & Udang Kapur & $1,3-1,3(1,30)$ & 5 \\
Parapenaeopsis hardwickii & Udang Batu & $1,3-2,0(1,60)$ & 3 \\
Metapenaeopsis barbata & Udang Kapur & 1,3 & 1 \\
Metapenaeus tenuipes & Udang Kapur & 1,9 & 1 \\
Parapenaeopsis maxillipedo & Udang Batu & 1,4 & 1 \\
\hline Total & & & $\mathbf{8 2 1}$ \\
\hline
\end{tabular}

Pengamatan kebiasaan makanan hanya dilakukan pada udang penaeid dengan jumlah sampel e > 30 ekor agar dapat mewakili populasi secara statistik. Hasil pengamatan kebiasaan makanan, perhitungan luas relung dan tingkat trofik 8 jenis udang penaeid dominan disajikan pada Tabel
2. Kebiasaan makanan udang penaeid berbeda tergantung spesiesnya. Penaeus monodon dan Penaeus sp. memiliki makanan utama berupa krustasea (mikrokrustasea atau potongan krustasea) sementara jenis udang penaeid lainnya ada yang makanan utamanya detritus dan moluska. 
Tabel 2. Kebiasaan makanan, luas relung dan tingkat trofik udang-udang penaeid di perairan Aceh Timur Table 2. Food habits, niche breadth and trophic level of penaeid prawns in East Aceh waters

\begin{tabular}{|c|c|c|c|c|c|c|c|c|c|c|}
\hline \multirow{2}{*}{ No } & \multirow{2}{*}{ Spesies Udang Penaeid } & \multicolumn{7}{|c|}{ Index of preponderance $(\%)$} & \multirow{2}{*}{$\begin{array}{c}\text { Tingkat } \\
\text { Trofik }\end{array}$} & \multirow{2}{*}{$\begin{array}{l}\text { Luas } \\
\text { Relung }\end{array}$} \\
\hline & & $\mathbf{A}$ & B & $\mathrm{C}$ & D & $\mathbf{E}$ & $\mathbf{F}$ & $\mathbf{G}$ & & \\
\hline 1 & $\begin{array}{l}\text { Metapenaeus } \\
\text { brevicornis }\end{array}$ & 16,4 & 46,1 & 27,8 & 8,8 & 0,9 & & & 2,69 & 3,08 \\
\hline 2 & $\begin{array}{l}\text { Parapenaeopsis stylifera } \\
\text { coromandelica }\end{array}$ & 53,4 & 11,6 & 25,0 & 10,0 & & & & 3,23 & 2,70 \\
\hline 3 & Penaeus monodon & 33,6 & 13,6 & 48,9 & 3,9 & & & & 3,27 & 2,69 \\
\hline 4 & Penaeus sp. & 10,9 & 19,3 & 65,2 & 4,6 & & & & 3,15 & 2,10 \\
\hline 5 & Metapenaeus ensis & 4,3 & 65,0 & 29,1 & 0,3 & 0,2 & & 1,1 & 2,52 & 1,96 \\
\hline 6 & Fenneropenaeus indicus & 67,3 & 24,5 & 3,8 & 4,3 & 0,1 & & & 3,13 & 1,93 \\
\hline 7 & $\begin{array}{l}\text { Fenneropenaeus } \\
\text { merguiensis }\end{array}$ & 71,9 & 12,8 & 12,2 & 3,1 & & & & 3,33 & 1,82 \\
\hline 8 & Metapenaeus dobsoni & 3,8 & 92,6 & 0,3 & 2,3 & 0,9 & 0,1 & & 2,08 & 1,16 \\
\hline
\end{tabular}

Keterangan makanan: $\mathrm{A}=$ Moluska; $\mathrm{B}=$ Detritus; $\mathrm{C}=$ Krustasea; $\mathrm{D}=$ Makrofita; $\mathrm{E}=$ Zooplankton;

$$
\mathrm{F}=\text { Pasir; } \mathrm{G}=\text { Annelida }
$$

Tingkat trofik udang penaeid di Aceh Timur berkisar antara $2,08-3,27$. Udang penaeid didominasi oleh tingkat trofik omnivora dengan 5 jenis preferensi makanan hewani. Metapenaeus brevicornis dan M. ensis merupakan omnivora dengan preferensi makanan nabati dan hanya M. dobsoni yang bersifat detritivor atau berada pada tingkat trofik terendah di komunitas udang penaeid di Aceh Timur.

Luas relung udang penaeid berkisar antara 1,16-3,08. Semakin tinggi luas relung maka kemampuan memanfaatkan sumber daya makanan alami akan lebih tinggi sehingga mampu beradaptasi lebih baik. Udang windu termasuk memiliki luas relung yang relatif tinggi sehingga memiliki alternatif makanan alami yang lebih banyak sehingga relatif mampu beradaptasi. Hal tersebut menyebabkan populasi udang windu cenderung menjadi lebih dominan dibanding udang penaeid yang lain karena kemampuan memanfaatkan sumber daya makanan alaminya yang lebih baik.

Dendrogram hasil analisis multivariat menunjukkan bahwa udang penaeid yang memiliki kesamaan kebiasaan makanan akan mengelompok seperti Penaeus monodon dengan Penaeus sp., Fenneropenaeus indicus, F. merguiensis dan Parapenaeopsis stylifera coromandelica serta Metapenaeus brevicornis dengan M. ensis (Gambar 2). Komunitas udang penaeid yang mengelompok cenderung memiliki interaksi trofik makanan yang lebih tinggi karena kesamaan dalam hal pemanfaatan sumber daya makanan. Metapenaeus dobsoni cenderung terpisah karena sifatnya yang detritivor sehingga peluang interaksi dengan jenis udang penaeid lainnya relatif kecil.

Hasil analisis multivariat tersebut diperkuat dengan perhitungan indeks Pianka yang menggambarkan tumpang tindih relung makanan antarjenis udang penaeid di perairan Aceh Timur (Gambar 3). Terlihat bahwa spesies udang penaeid yang mengelompok pada dendrogram (Gambar 2) cenderung memiliki nilai indeks Pianka yang menunjukkan peluang terjadinya kompetisi tinggi (Gambar 3).

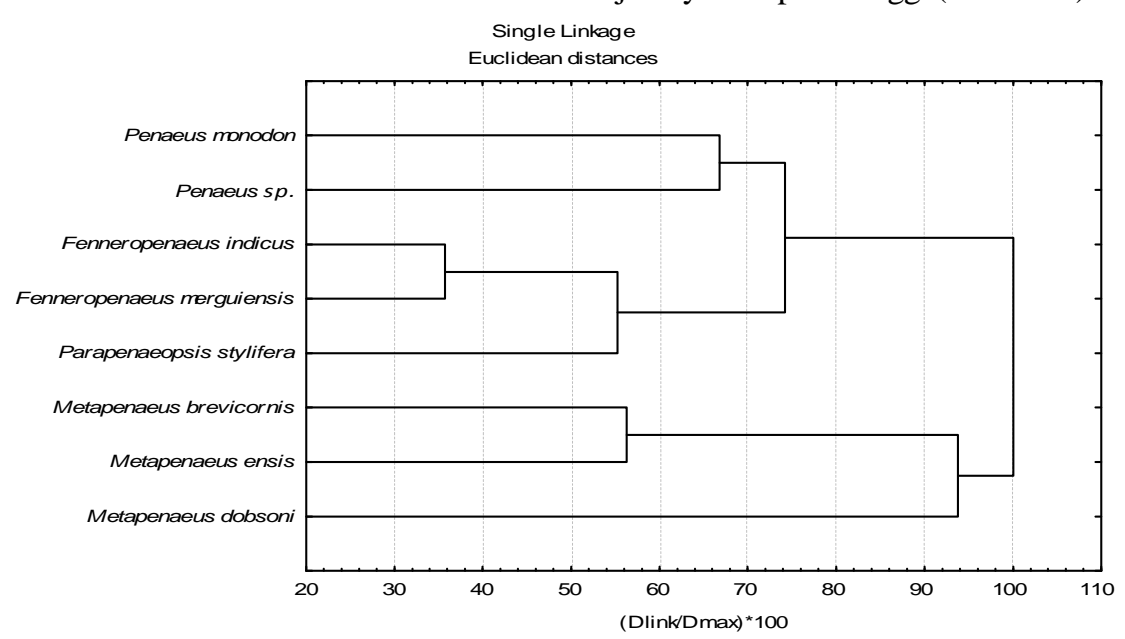

Gambar2. Analisis pengelompokan kebiasaan makanan komunitas udang penaeid di Aceh Timur.

Figure 2. Cluster analysis of food habits of penaeid shrimp communities in East Aceh . 


\begin{tabular}{|c|c|c|c|c|c|c|c|c|c|}
\hline No & $\begin{array}{l}\text { Spesies Udang } \\
\text { Penaeidae }\end{array}$ & 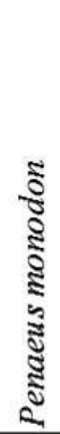 & 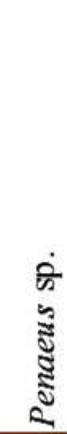 & 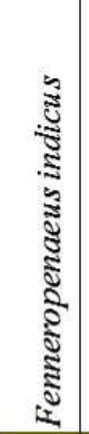 & 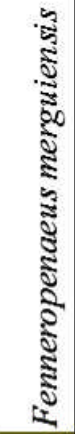 & 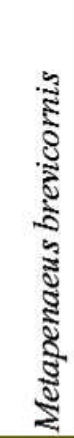 & 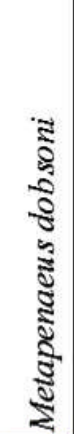 & 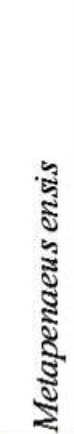 & 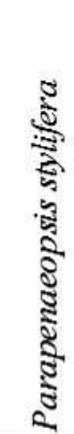 \\
\hline 1 & Penaeus monodon & & 0,91 & 0,64 & 0,71 & 0,74 & 0,25 & 0,56 & 0,87 \\
\hline 2 & Penaeus sp. & & & 0,30 & 0,36 & 0,74 & 0,29 & 0,65 & 0,59 \\
\hline 3 & Fenneropenaeus indicus & & & & 0,98 & 0,58 & 0,38 & 0,39 & 0,92 \\
\hline 4 & Fenneropenaeus merguiensis & & & & & 0,50 & 0,21 & 0,28 & 0,96 \\
\hline 5 & Metapenaeus brevicornis & & & & & & 0,83 & 0,95 & 0,63 \\
\hline 6 & Metapenaeus dobsoni & & & & & & & 0,91 & 0,23 \\
\hline 7 & Metapenaeus ensis & & & & & & & & 0,40 \\
\hline 8 & Parapenaeopsis stylifera & & & & & & & & \\
\hline
\end{tabular}

Gambar 3. Tumpang tindih relung makanan komunitas udang penaeid di perairan Aceh Timur.

Figure 3. Niche overlap of food habits of penaeid shrimp communities in East Aceh waters.

\section{Bahasan}

Perairan Aceh Timur dikenal sebagai salah satu habitat udang penaeid di Aceh yang menghasilkan indukan yang unggul, terutama udang windu (Riani, 2000; Wardana, 2011). Kondisi tersebut terkait dengan faktor genetiknya yang relatif lebih baik dibandingkan di daerah lain. Aceh Timur memiliki panjang garis pantai mencapai $161,18 \mathrm{~km}$ yang didominasi oleh mangrove dan terdapat beberapa sungai besar yang bermuara ke laut sehingga turut mendukung bagi keberadaan udang penaeid dan biota perairan lainnya (Direktorat Jenderal Kelautan Pesisir dan Pulau-Pulau Kecil, 2008). Keberadaan mangrove memiliki peranan penting dalam mendukung kehidupan biota perairan, termasuk udang penaeid karena seresah mangrove dapat menjadi sumber nutrisi bagi udang penaeid dan organisme lainnya seperti zooplankton, makrozoobentos dan lain-lain yang membentuk jejaring rantai makanan yang kompleks di ekosistem mangrove (Chong et al., 2000).

Kebiasaan makanan udang-udang penaeid di perairan Aceh Timur didominasi oleh makanan utama berupa moluska, krustasea, detritus, makrofita dengan makanan tambahan berupa zooplankton, pasir dan annelida. Makanan udang penaeid tersebut berasosiasi dengan keberadaan mangrove. Fenomena tersebut relatif hampir sama dengan kebiasaan makan udang penaeid yang pernah dilaporkan dan umumnya berupa makanan yang terdapat di dasar seperti detritus dan makrozoobentos lainnya (Dall et al., 1990). Hasil penelitian sebelumnya menunjukkan $P$. monodon memiliki makanan alami berupa krustasea, moluska, detritus, makrofita, annelida, polichaeta, ikan, fitoplankton, zooplankton serta terkadang lumpur dan pasir (Abu Hena \& Hishamuddin, 2012; Baskar et al., 2013; El Hag, 1984; Hermansah, 2000; Marte, 1980; Motoh, 1985; Thomas, 1972). Kebiasaan makanan Fenneropenaeus merguiensis terdiri atas zooplankton, detritus, kopepoda, moluska bivalvia, krustasea, polichaeta dan ikan (Chong \& Sasekumar, 1981). Adanya komponen makanan berupa krustasea diduga menunjukkan sifat kanibal pada beberapa udang penaeid. Sifat kanibal merupakan sifat yang umum pada semua krustasea, termasuk udang penaeid dimana udang yang lebih besar cenderung akan memangsa jenis yang lebih kecil atau yang dalam kondisi lemah seperti sedang melakukan proses moulting jika ketersediaan makanan kurang (Suharyanto et al., 2010; Suyanto \& Takarina, 2009).

Kebiasaan makanan udang penaeid akan berbeda tergantung pada daur hidupnya (Dall et al., 1990; Dall, 1968). Komunitas udang penaeid di Aceh Timur yang diamati pada penelitian ini umumnya berada pada fase yuwana hingga dewasa mengingat daur hidup udang penaeid pada fase tersebut banyak terdapat di ekosistem pesisir. Pada fase tersebut udang akan memilih makanan sesuai kebiasaan makanannya dimana kemampuan untuk memanfaatkan sumber daya makanan alami akan berbeda tergantung luas relungnya. Semakin tinggi luas relung maka udang penaeid akan bersifat generalis dalam memanfaatkan sumber daya makanan alami yang tersedia atau spesialis jika sebaliknya (Collwel \& Futuyma, 1971; Krebs, 1989).

Tingkat trofik komunitas udang penaeid di Aceh Timur berkisar antara 2,08 - 3,27 dan didominasi oleh kategori 
omnivora dengan preferensi makanan hewani. Kondisi tersebut juga sama dengan beberapa literatur dimana udang penaeid umumnya bersifat omnivora. Hanya $M$. dobsoni yang bersifat detritivor. Habitat udang penaeid umumnya berada di dasar sehingga sering menjadi pemangsa bagi makrozoobentos kecil, terkadang menjadi pemakan bangkai atau detritus sehingga cenderung bersifat opportunistik dalam kebiasaan makanannya (Chan, 1998; Dall et al., 1990; Motoh, 1985).

Luas relung komunitas udang penaeid di perairan Aceh Timur berkisar antara 1,16-3,08. Kisaran luas relung udang penaeid di Aceh Timur lebih luas dibandingkan penelitian Purnamaningtyas \& Hedianto (2015) yang melaporkan luas relung udang penaeid di pesisir Kubu Raya Kalimantan Barat berkisar antara 1,20-2,70. Secara umum, hampir sebagian besar udang penaeid di perairan Aceh Timur bersifat generalis karena komposisi makanannya yang bervariasi. Luas relung bersifat fluktuatif yang akan meningkat jika ketersediaan makanan rendah dan cenderung menurun jika ketersediaan makanan tinggi (Tse et al., 2008). Luas relung udang penaeid di alam cenderung lebih besar dibandingkan di tambak budidaya karena ketersediaan makanan relatif banyak dan tidak dipengaruhi oleh kepadatan (Hermansah, 2000).

Adanya kesamaan habitat dan beberapa jenis makanannya, maka terdapat potensi terjadinya kompetisi pada komunitas udang penaeid di perairan Aceh Timur terutama pada beberapa kelompok udang penaeid sebagaimana terlihat pada dendrogram (Gambar 2) dan indeks Pianka (Gambar 3) yaitu antara Penaeus monodon dengan Penaeus sp., Fenneropenaeus indicus, F. merguiensis dengan Parapenaeopsis stylifera coromandelica serta Metapenaeus brevicornis dengan M. ensis. Berdasarkan kriteria Moyle \& Senanayake (1984), tumpang tindih relung makanan antarjenis udang penaeid di perairan Aceh Timur berpotensi terjadinya kompetisi yang relatif tinggi, umumnya pada udang penaeid dalam satu genus yang sama. Tumpang tindih relung yang tinggi antar jenis udang penaeid di Aceh Timur walaupun demikian bukan merupakan faktor pembatas jika ketersediaan makanan di habitatnya mencukupi (Gocke et al., 2013).

Keberadaan sumber daya makanan di perairan Aceh Timur akan berpengaruh terhadap populasi komunitas udang penaeid sehingga pengelolaan perikanan udang di Aceh Timur sebaiknya harus dilakukan dengan pendekatan ekosistem. Pengelolaan habitat pesisir merupakan bagian yang tidak terpisahkan dari pengelolaan perikanan udang karena terdapat hubungan timbal balik dan adanya rantai energi dalam ekosistem tersebut yang semuanya saling mempengaruhi. Oleh karena itu, dalam menjaga agar interaksi trofik antar jenis komunitas udang penaeid tetap seimbang, maka keberadaan mangrove di sekitar perairan Aceh Timur harus tetap terjaga mengingat peranan mangrove yang cukup besar bagi penyediaan nutrisi dan hara untuk mendukung keberlangsungan sistem jejaring makanan bagi komunitas udang penaeid dan organisme akuatik lainnya (Dall et al., 1990).

\section{KESIMPULAN}

Komunitas udang penaeid di perairan pantai Aceh Timur terdapat sekitar 20 jenis udang pada stadia yuwana hingga dewasa. Kebiasaan makanan pada 8 jenis udang penaeid dominan berbeda tergantung spesiesnya dengan makanan utama berupa krustasea, detritus dan moluska. Interaksi trofik menunjukkan terdapat peluang kompetisi yang tinggi antara Penaeus monodon dengan Penaeus sp., Fenneropenaeus indicus, F. merguiensis dan Parapenaeopsis stylifera coromandelica serta Metapenaeus brevicornis dengan $M$. ensis karena memanfaatkan sumber daya makanan yang sama.

\section{PERSANTUNAN}

Tulisan ini merupakan kontribusi dari kegiatan "Penelitian Kawasan Konservasi Induk Udang Windu (Penaeus monodon) di Pantai Timur Aceh, Kabupaten Aceh Timur" Tahun Anggaran 2014 - 2016 di Balai Penelitian Pemulihan dan Konservasi Sumber Daya Ikan, Jatiluhur, Purwakarta. Terima kasih diucapkan kepada Dr. Didik Wahju Hendro Tjahjo selaku penanggung jawab kegiatan untuk izin, saran dan diskusi selama proses penulisan.

\section{DAFTARPUSTAKA}

Abu Hena, M. K., \& Hishamuddin, O. (2012). Food selection preference of different ages and sizes of black tiger shrimp, Penaeus monodon Fabricius, in tropical aquaculture ponds in Malaysia. African Journal of Biotechnology, 11(22), 6153-6159.

Al-Maslamani, I., Vay, L. L., Kennedy, H., \& Jones, D. A. (2007). Feeding ecology of the grooved tiger shrimp Penaeus semisulcatus De Haan (Decapoda: Penaeidae) in inshore waters of Qatar, Arabian Gulf. Mar. Biol., $150,627-637$.

Asriyana. (2011). Interaksi trofik komunitas ikan sebagai dasar pengelolaan sumber daya ikan di perairan Teluk Kendari Sulawesi Tenggara. (p. 106). Disertasi. Sekolah Pascasarjana Institut Pertanian Bogor.

Bakhtiyar, Y., Lakhnotra, R., \& Langer, S. (2014). Natural food and feeding habits of a locally available freshwa- 
ter prawn Macrobrachium dayanum (Henderson) from Jammu waters, North India. International Journal of Fisheries and Aquatic Studies, 2(3), 33-38.

Baskar, S., Narasimhan, N., Daniel, G. S., Ravichelvan, R., Sukumaran, M., \& Anandaraj, T. (2013). Food and feeding habits of Penaeus monodon (Fabricius) from Mallipattinam Coast in ThanjavurDist, Tamil Nadu, India. International Journal of Research in Biological Sciences, 3(1), 1-4.

Chan, T. Y. (1998). Shrimp and prawn. In K. E. Carpenter \& V. H. Niem (Eds.), FAO Identification guide for fishery purposes. The living marine resources of the Western Central Pacific. Vol. 2. Cephalopods, Crustaceans, Holuthurians, and Sharks (pp. 687-1396). Rome, Italy: Food and Agriculture Organization.

Chaves, P. T., \& Umbria, S. C. (2003). Changes in the diet composition of transitory fishes in coastal systems, Estuary and Continental shelf. Brazilian Archives of Biology and Technology, 46, 41-46.

Chong, V. C., Low, C. B., \& Ichikawa, T. (2000). Contribution of mangrove detritus to juvenile prawn nutrition: A dual stable isotope study in a Malaysian mangrove forest. Marine Biology, 138(1), 77-86.

Chong, V. C., \& Sasekumar, A. (1981). Food and feeding habits of the white prawn Penaeus merguiensis. Marine Ecology Progress Series, 5, 185-191.

Collwel, R. K., \& Futuyma, D. J. (1971). On the measurement of niche breadth and overlap. Ecology, 52(4), 567-576.

Dall, W. (1968). Food and feeding of some Australian Penaeid shrimp. FAO Fish. Rep, 57, 251-258.

Dall, W., B.J., H., Rothlisberg, P. C., \& Staples, D. C. (1990). The biology of the Penaeidae. In J. H. S. Blaxter \& A. J. Southward (Eds.), Advances in Marine Biology, Vol. 27. (p. 489). London: Academic Press Inc.

Direktorat Jenderal Kelautan Pesisir dan Pulau-Pulau Kecil. (2008). Penjajagan potensi investasi kawasan pesisir Kabupaten Aceh Timur Provinsi Nanggroe Aceh Darussalam. Laporan Pendahuluan. Direktorat Tata Ruang Laut, Pesisir dan Pulau-Pulau Kecil, Ditjen KP3K (p. 17). Jakarta: Departemen Kelautan dan Perikanan.

Effendie, M. I. (2002). Biologi perikanan (p. 163). Yogyakarta: Yayasan Pustaka Nusatama.
El Hag, E. A. (1984). Food and food selection of the Penaeid prawn Penaeus monodon (Fabricius). Hydrobiologia, 110(1), 213-217.

Erawati, D. A. (2000). Sistem informasi identifikasi jenis udang Penaeid dan pola penyebarannya di perairan Indonesia (p. 61). Skripsi.. Fakultas Perikanan dan Ilmu Kelautan Institut Pertanian Bogor.

Gocke, C., Kaschek, N., \& Meyer, E. I. (2013). Diet of fishes in a detritus-based sandy lowland brook. Limnologica, $43,451-459$.

Hedianto, D. A., Suryandari, A., \& Tjahjo, D. W. H. (2016). Dinamika populasi dan status pemanfaatan udang windu (Penaeus monodon, Fabricus 1789) di Perairan Aceh Timur, Provinsi Aceh. J.Lit.Perikan.Ind., 22(2), 71-82.

Hermansah, A. (2000). Kebiasaan makanan udang windu (Penaeus monodon Fabr.) di tambak tradisional Sylvofishery Desa Karangsong Kecamatan Indramayu, Jawa Barat (p. 77). Skripsi. Institut Pertanian Bogor.

Holthuis, L. B. (1980). FAO Species catalogue: Shrimps and prawns of the world-an annotated catalogue of species of interest to fisheries. FAO.Fish. Synop., 125(1), 271.

Kembaren, D. D., \& Ernawati, T. (2015). Dinamika populasi dan estimasi rasio potensi pemijahan udang jerbung (Penaeus merguiensis de Man, 1907) di Perairan Teluk Cenderawasih dan Sekitarnya, Papua. J.Lit.Perikan.Ind., 21(3), 201-210.

Krebs, C. J. (1989). Ecological methodology (p. 652). New York: Harper and Row Publisher.

Kulkarni, B. G., Deshmukh, V. D., \& Kulkarni, V. R. (1999). Food and feeding habit of a Penaeid prawn Metapeneopsis stridulans (Alcock 1905). Journal Bombay Natural History Society, 96(2), 262-267.

Lante, S., Laining, A., \& Parenrengi, A. (2015). Performa reproduksi induk udang windu (Penaeus monodon Fab.) jantan alam dan domestikasi tambak. In Prosiding Forum Inovasi Teknologi Akuakultur (pp. 693-700). Jakarta: Kementerian Kelautan dan Perikanan.

Lima, J., Garcia, J. S., \& Silva, T. . (2014). Natural diet and feeding habits of a freshwater prawn (Macrobrachium carcinus: Crustacea, Decapoda) in the estuary of the Amazon River. Acta Amazonica, 44(2), 235-244. 
Marte, C. L. (1980). The food and feeding habit of Penaeus monodon Fabricius collected from Makato River, Aklan, Philippines (Decapoda Natantia). Crustaceana, $38(3), 225-236$

Motoh, H. (1985). Biology and ecology of Penaeus monodon. In Y. Taki, J. H. Primavera, \& J. A. Llobrera (Eds.), Proceedings of the First International Conference on the Culture of Penaeid Prawns/Shrimps, 4-7 December 1984, Iloilo City, Philippines (pp. 2736). Iloilo City, Philippines: Aquaculture Department, Southeast Asian Fisheries Development Center.

Moyle, P. B., \& Senanayake, F. R. (1984). Resource partitioning among the fishes of rainforest streams in Sri Lanka. J. Zool. Lond., 202, 195-223.

Natarajan, A. V., \& Jhingran, A. G. (1961). Index of preponderance-a method of grading the food elements in the stomach analysis of fishes. Indian Journal of Fisheries, 8(1), 54-59.

Nybakken, J. W. (1992). Biologi laut: suatu pendekatan ekologis (p. 459). Jakarta: PT Gramedia Pustaka Utama.

Odum, E. P. (1993). Dasar-dasar ekologi (edisi ketiga) (p. 697). Yogyakarta: Gadjah Mada Univesity Press.

Palomares, M. L. D., \& Pauly, D. (Eds.). (2014). SeaLifeBase. World Wide Web electronic publication. www.sealifebase.org. version $(06 / 2014)$.

Pangesti, T. P. (2011). Model Pengelolaan Sumberdaya Udang Penaeidae spp di Kabupaten Cilacap Provinsi Jawa Tengah (p. 73). Tesis. Institut Pertanian Bogor.

Pauly, D., Froese, R., Sa-a, P. S., Palomares, M. L., Christensen, V., \& Rius, J. (2000). TrophLab Manual. Manila: ICLARM.

Pianka, E. R. (1974). The structure of lizard communities. Annu. Rev. Ecol. Syst., 4, 53-74.

Preston, N. P., Burford, M. A., Coman, E. E., \& Rothlisberg, P. C. (1992). Natural diet of larval Penaeus merguiensis (Decapoda: Penaeidae) and its effect on survival. Marine Biology, 113, 181-191.

Purnamaningtyas, S. E., \& Hedianto, D. A. (2015). Kebiasaan makan dan luas relung beberapa jenis udang dan ikan di pesisir Muara Kakap, Kalimantan Barat. BAWAL, 7(2), 95-102.

Purwanto. (2015). Potential production of demersal fish stock in the Malacca Strait of Indonesia. Ind.Fish. Res. J., 21(1), 45-52.
Riani, E. (2000). Kemungkinan penggunaan induk udang windu (Penaeus monodon Fab) Binuangeun sebagai pengganti induk Aceh yang sudah mengalami gejala tangkap lebih. Media Konservasi, VII(1), 29-36.

Romimohtarto, K., \& Juwana, S. (2009). Biologi laut: ilmu pengetahuan tentang biota laut (p. 540). Jakarta: Penerbit Djambatan.

Sentosa, A. A., \& Satria, H. (2011). Relung ekologi beberapa ikan target hasil tangkapan bubu di sekitar terumbu buatan perairan Teluk Saleh, Nusa Tenggara Barat. J.Lit.Perikan.Ind., 17(3), 209-219.

Suharyanto, Tjaronge, M., \& Mansyur, A. (2010). Budidaya multitropik udang windu (Penaeus monodon), rumput laut (Gracilaria sp.), dan ikan bandeng (Chanos chanos) di tambak. In Prosiding Forum Inovasi Teknologi Akuakultur 2010 (pp. 285294). Jakarta: Kementerian Kelautan dan Perikanan.

Suman, A., Rijal, M., \& Nurasa, T. (1992). Perikanan udang di Perairan Pidie, Aceh. J. Lit. Perikanan Laut, 69, 43 51.

Sumiono, B. (2012). Status sumberdaya perikanan udang Penaeid dan alternatif pengelolaannya di Indonesia. J. Kebijak. Perikan. Ind., 4(1), 27-34.

Suyanto, S. R., \& Takarina, E. P. (2009). Panduan budidaya udang windu (p. 116). Jakarta: Penebar Swadaya.

Thomas, M. M. (1972). Food and feeding habits of Penaeus monodon Fabricius from Korapuzha estuary. Indian Journal of Fisheries, 19(1 \& 2), 202-204.

Tse, P., Nip, T. H. M., \& Wong, C. K. (2008). Nursery function of mangrove: A comparison with mudflat in terms of fish species composition and fish diet. Estuarine, Coastal and Shelf Science, 80, 235-242.

Wardana, M. Y. (2011). Kajian prospek komoditas induk udang windu pada kawasan pesisir perairan pantai di daerah Kabupaten Aceh Besar. Jurnal Agrisep, 12, 31-39.

Wassenberg, T. J., \& Hill, B. J. (1993). Diet and feeding behaviour of juvenile and adult banana prawns Penaeus merguiensis in the Gulf of Carpentaria, Australia. Mar. Ecol. Prog. Ser., 94, 287-295.

Widodo, J., \& Suadi. (2006). Pengelolaan sumber daya perikanan laut (p. 252). Yogyakarta: Gadjah Mada University Press. 
Sentosa, A.A., et al/BAWAL. 9 (3) Desember 2017: 197-206

Wijaya, D. (2015). Interaksi Trofik Ikan dalam Pemanfaatan Makanan Alami di Estuari Segara Anakan Bagian Barat,
Cilacap (p. 95). Tesis. Sekolah Pascasarjana Universitas Diponegoro. 